Wiktor Dynarski

ORCID: 0000-0003-2469-3393

Ośrodek Badań Społecznych nad Seksualnością

Uniwersytet Warszawski

\title{
Gdy dezinformacja znajduje podatny grunt. TERF-izm, antynaukowość, teorie spiskowe i zawłaszczanie dyskursu praw człowieka
}

Fake newsy, alternatywne fakty, spekulacje, teorie spiskowe, mylne informacje, a czasem również zaplanowana dezinformacja to zjawiska, z którymi zarówno media tradycyjne, jak i społecznościowe mierzą się codziennie ${ }^{1}$. Niektóre mają z nimi styczność w ramach misji prostowania nieprawdziwych informacji - szczególnie tych, które mogą zaszkodzić społeczeństwu (na przykład poprzez szerzenie antynaukowych twierdzeń) - inne zaś przeciwnie, nie tylko je szerzą, lecz także wspierają ich kolejne wersje poprzez niepodejmowanie konfrontacji, oferowanie przestrzeni na nieograniczoną dyskusję bez jakiegokolwiek pomocnego komentarza, a czasem również umyślne promowanie osób propagujących szkodliwe treści.

W 2020 roku, gdy cały świat musiał zmierzyć się z pandemią wirusa SARS-CoV-2 i wywoływanej przez niego choroby COVID-19, również sama dezinformacja ${ }^{2}$ urosła

1 W różnorodnych źródłach można spotkać się z określeniem XXI wieku jako „ery fake newsów”, jednakże jest to bardzo znany historii fenomen, który może być nawet starszy niż idea „newsów” lub wiadomości jako takich i który — przynajmniej w Europie - ma swoje korzenie w szerzeniu kłamstw i propagandy na temat grup marginalizowanych, na przykład społeczności żydowskiej w XV wieku i wcześniej. Zob. J. Soll, The long and brutal history of fake news, „Politico Magazine”, 2016, https://www.politico. com/magazine/story/2016/12/fake-news-history-long-violent-214535 (dostęp: 10.01.2021).

${ }^{2}$ Warto w tym miejscu odróżnić mylne informacje (ang. misinformation) od dezinformacji (ang. disinformation) - podczas gdy to pierwsze zjawisko najczęściej wynika z niewiedzy osób je szerzą- 
do miary swojej własnej, specyficznej pandemii, a wraz z nią wzrosły też niechęć oraz brak zaufania do świata nauki ${ }^{3}$. Kolejne fale fałszerstw dotyczyły nie tylko wirusa jako takiego, lecz także jego pochodzenia, rozwoju i sposobu, w jaki się przemieszcza. Nieprawdziwe informacje nierzadko urastały przy tym do rangi teorii spiskowych — od twierdzeń, jakoby pandemia była celowym działaniem chińskiego rządu (samodzielnym lub we współpracy $z$ innymi), przez hipotezy dotyczącego jego laboratoryjnego pochodzenia, aż do oskarżeń miliardera Billa Gatesa o kontrolowanie umysłów globalnej populacji za pomocą ukrytych w szczepionkach mikroczipów ${ }^{4}$.

Pandemia nie była jednakże w stanie powstrzymać innych teorii spiskowych oraz dezinformacji związanych z kwestiami zdrowotnymi czy prawami człowieka. W niektórych przypadkach - jak się wydaje - pozwoliła fałszywym informacjom szerzyć się o wiele szybciej i jeszcze łatwiej znajdować podatny grunt. Tak stało się $\mathrm{z}$ antytranspłciowym aktywizmem, którego propagatorki (w większości, choć nie tylko, cispłciowe ${ }^{5}$ kobiety) pod osłoną troski o prawa i bezpieczeństwo kobiet, a także poprzez zawłaszczanie elementów dyskursu praw człowieka ${ }^{6}$ oraz historycznych aspektów radykalnego feminizmu drugiej fali, dały się poznać światu jako TERF-ki

cych oraz braku weryfikacji, drugie zależy od aktywnego czynnika, to jest osoby lub instytucji, która wprowadza kogoś celowo w błąd. Por. Dezinformacja a fałszywe informacje, „Poradnia Językowe PWN" 2017, https://sjp.pwn.pl/poradnia/haslo/i-Dezinformacja-i-a-i-falszywe-informacje-i; $18184 . h t m l$ (dostęp: 10.01.2021).

3 Niechęć ta była być może związana z nieumiejętnością oceny zmieniających się wytycznych zachowań prewencyjnych, na przykład noszenia maseczek czy (nie)wychodzenia z domu, a także z drastycznymi efektami gospodarczymi, jakie wynikły z konieczności wprowadzania różnorodnych obostrzeń, chociażby kwarantanny czy ograniczania swobody ruchu. Obecnie zaś wydaje się oscylować wokół wątpliwości dotyczących powstania szczepionki na COVID-19.

${ }^{4}$ Co interesujące, podobnej teorii spiskowej trudno szukać o Dolly Parton, której działalność filantropijna wsparła badania Moderny nad szczepionką na COVID-19. Zob. Ł. Kamiński, Bohaterka, na jaką ludzkość nie zasługuje. Jak Dolly Parton przyłożyła się do walki z koronawirusem, wyborcza.pl, 2020, https://wyborcza.pl/7,113768,26520888,bohaterka-na-jaka-ludzkosc-nie-zasluguje-jak-dolly-parton.html (dostęp: 11.01.2021).

${ }^{5}$ Cispłciowość oznacza odwrotność transpłciowości. W bardzo szerokim ujęciu osoba transpłciowa to ktoś, kto nie identyfikuje się z płcią przypisaną po urodzeniu, cispłciowa zaś to taka, której tożsamość jest z nią zgodna. Osoby transpłciowe mogą być kobietami, mężczyznami, osobami niebinarnymi, a także innymi, w zależności od tego, w jaki sposób opisują swoje doświadczenie płci. Por. W. Dynarski, A.M. Kłonkowska, Gender i inne kłopotliwe terminy. Czyli jak mówić o różnorodności i (nie)normatywności płciowej i seksualnej, [w:] U. Kluczyńska, W. Dynarski, A.M. Kłonkowska, Poza schematem. Społeczny konstrukt płci i seksualności, Gdańsk 2016, s. 14.

${ }^{6}$ Chociażby poprzez Deklarację praw kobiet w oparciu o płeć biologiczna - dokument powstały jako odpowiedź na „Zagrożenie wychodzące od organizacji, które chcą zmienić definicję kobiety”. Zob. Declaration on Women's Sex-based Rights: Summary, https://www.womensdeclaration.com/en/ declaration-womens-sex-based-rights-summary/ (dostęp: 11.01.2021).

7 Z angielskiego TERF - Trans Exclusionary Radical Feminism, to jest radykalny feminizm wykluczający osoby transpłciowe. O tym, dlaczego w przypadku tej działalności można mówić o zawłaszczaniu dyskursu, zob. N. Kuta, Feminizm musi być trans-inkluzywny albo będzie martwy, „Codziennik Feministyczny” 2020, http://codziennikfeministyczny.pl/feminizm-musi-byc-trans-inkluzywny-albo- 
W Europie ten rodzaj antytranspłciowego aktywizmu zaczął trafiać do świadomości szerszej społeczności w 2017 roku, kiedy ówczesna premier Zjednoczonego Królestwa Theresa May zapowiedziała od dawna oczekiwaną reformę ustawy z 2004 roku regulującej uzgodnienie płci - Gender Recognition Act (GRA) - w której transpłciowa społeczność brytyjska pokładała nadzieję na ułatwienie procedury zmiany danych osobowych oraz jej odpatologizowanie, to jest usamodzielnienie od żmudnego i nastręczonego trudnościami procesu medycznego. Rok później, kiedy rząd brytyjski umożliwił konsultacje publiczne w sprawie zmiany GRA - jak wskazują Ruth Pearce, Sonja Erikainen i Ben Vincent ${ }^{8}$ - różnorodne organizacje przedstawiające się jako działające na rzecz kobiet i/lub lesbijek podjęły działania mające na celu sprzeciwić się zapowiadanym zmianom. Prowadzone przez nie kampanie szybko zostały przechwycone przez znane i popularne media, na przykład „Guardiana” i BBC, a w rezultacie doprowadziły do zaprzestania prac nad zmianą ustawy. Bezkrytyczna popularyzacja nastawień antytranspłciowych spowodowała również wzrost zbrodni $\mathrm{z}$ nienawiści o $81 \%{ }^{9}$.

Planowana aktualizacja GRA miała na celu nie tylko ułatwienie osobom transpłciowym procesu uzgodnienia płci, lecz także wprowadzenie najwyższego standardu praw człowieka w tym zakresie, który jest już dostępny w kilku państwach Europy (między innymi w Dani, na Islandii, w Irlandii, Luksemburgu, na Malcie czy w Norwegii ${ }^{10}$ ) i który jak dotąd nie spowodował w żadnym stopniu marginalizacji czy wymazania ciskobiet przez osoby transpłciowe z przestrzeni publicznych ani ograniczenia ich praw. Te ostatnie obawy wydają się obecne również wśród niektórych polskich aktywistek feministycznych, na przykład Urszuli Kuczyńskiej, która w wywiadzie dla czasopisma „Wysokie Obcasy” nawoływania do włączenia osób transpłciowych do dyskursu praw reprodukcyjnych uznaje za odwracanie uwagi od praw (cis)kobiet ${ }^{11}$. Kuczyńska nawoływania te widzi jako coś nowego, ignorując tym samym ponad dekadę tradycji polskiego transaktywizmu (i jego poprzednie wcielenia), który od wczesnych lat związany był ze współpracą z grupami feministycznymi ${ }^{12}$.

bedzie-martwy/ (dostęp: 11.01.2021). Aktywiści i aktywistki związane z tym ruchem czasem stosują wobec siebie również określenie gender critical.

8 Zob. R. Pearce, S. Erikainen, B. Vincent, TERF wars: An introduction, „The Sociological Review” 68, 2020, nr 4, s. 677-698.

9 Zob. Transgender hate crimes recorded by police go up 81\%, BBC, 2019, https://www.bbc.com/ news/uk-48756370 (dostęp: 11.01.2021).

10 Por. Trans Rights Europe \& Central Asia Index 2020, TGEU, https://tgeu.org/trans-rights-europe-central-asia-index-maps-2020/ (dostęp: 11.01.2021).

11 Zob. K. Romanowska, Mam wątpliwości, czy zamiana „kobiet” na „osoby z macicami” to postawa lewicowa. Wywiad z Urszula Kuczyńska, „Wysokie Obcasy” 2020, https://www.wysokieobcasy.pl/ wysokie-obcasy/7,163229,26597103,kobiety-w-polsce-jeszcze-nie-zajely-miejsca-na-scenie.html (dostęp: 11.01.2021).

12 W sprawozdaniu z działalności Fundacji Trans-Fuzja za 2010 rok można przeczytać o udziale osób związanych z organizacją w Warszawskiej Manifie, który był związany z nadzieją, że „w przy- 
Antytranspłciowy aktywizm brytyjski, jak wskazują osoby autorskie TERF wars, zidentyfikował również priorytety, które nie tylko skonstruowano w sposób antagonizujący osoby transpłciowe w oczach reszty społeczeństwa, lecz także oparto na obalonych już tezach i mitach, które mimo wszystko pozostają kontrowersyjne dla osób niezaznajomionych z transpłciowością. Wśród mitów znalazły się między innymi: (1) figura osoby trans (zwykle transkobiety) jako zagrażającej ciskobietom i dzieciom (ten ostatni to trop wykorzystywany także w retoryce antygejowskiej) ${ }^{13}$, (2) przedstawienie ułatwionego procesu uzgodnienia płci jako umożliwiającego prawne nadużycia (w związku z czym jedyną alternatywą ma być jego maksymalne utrudnienie ${ }^{14}$ ), a także (3) odmawianie osobom niepełnoletnim prawa do samostanowienia i otrzymania odpowiedniej pomocy terapeutycznej i medycznej ${ }^{15}$.

Choć w kontekście polskim antytranspłciowy aktywizm pod feministyczną egidą jest nowym zjawiskiem, jego źródeł można doszukać się też w kampaniach i działalności zachodnich aktywistek i aktywistów - propagowane przez niego obawy inspirowane są również znanymi tropami obecnymi w dyskursie anty-LGBT i antygenderowym, ściśle związanym z działalnością konserwatywną i nacjonalistyczną. Trudno orzec, w jaki sposób rozwinie się jego dalsza działalność, nie da się jednakże ukryć, biorąc pod uwagę przykład brytyjski, że niekonfrontowane mity, fałszywe informacje oraz dezinformacja - a także brak strategii oporu wobec nich - prowadzą do pogorszenia się sytuacji marginalizowanych społeczności będących celem krzywdzących narracji, w tym wypadku osób transpłciowych.

szłości pomogą one [inicjatywy feministyczne] także osobom transpłciowym" - 2010. Sprawozdanie $z$ działalności merytorycznej Fundacji Trans-Fuzja, transfuzja.org, 2011, http://fundacja.transfuzja. org/pl/artykuly/raporty_z_dzialalnosci/2010_sprawozdanie_z_dzialalnosci_merytorycznej_fundacji_transfuzja.htm (dostęp: 11.01.2021).

13 Zob. C. Jones, J. Slater, The toilet debate: Stalling trans possibilities and defending "women's protected spaces”, „The Sociological Review” 68, 2020, nr 4, s. 834-851.

14 Jest to argument niezwykle bliski uzasadnieniu prezydenckiego weta ustawy o uzgodnieniu płci w 2015 roku, które dodatkowo podważyło koncepcję samostanowienia i tożsamości płciowej jako takiej. Zob. Uzasadnienie do weta prezydenta: Ustawa o uzgodnieniu płci może prowadzić do destabilizacji norm społecznych, „Dziennik Gazeta Prawna” 2015, https://prawo.gazetaprawna.pl/ artykuly/897813,uzasadnienie-do-weta-prezydenta-ustawa-o-uzgodnieniu-plci-moze-prowadzic-dodestabilizacji-norm-spolecznych.html (dostęp: 11.01.2021).

15 Ten priorytet związany jest przede wszystkim z wytwarzaniem moralnej paniki podobnej do tej, jaka w Polsce miała miejsce w związku z wytycznymi Światowej Organizacji Zdrowia w sprawie edukacji seksualnej. Zob. M. Zabdyr-Jamróz, 3 mity na temat „Standardów edukacji seksualnej” WHO, Instytut Zdrowia Publicznego Collegium Medicum Uniwersytetu Jagiellońskiego, https://izp. wnz.cm.uj.edu.pl/pl/blog/3-mity-na-temat-standardow-edukacji-seksualnej-who/ (dostęp: 11.01.2021). 


\section{Bibliografia}

2010. Sprawozdanie z działalności merytorycznej Fundacji Trans-Fuzja, transfuzja.org, 2011, http:// fundacja.transfuzja.org/pl/artykuly/raporty_z_dzialalnosci/2010_sprawozdanie_z_dzialalnosci_merytorycznej_fundacji_transfuzja.htm.

Declaration on Women's Sex-based Rights: Summary, https://www.womensdeclaration.com/en/declaration-womens-sex-based-rights-summary/

Dezinformacja a fałszywe informacje, „Poradnia Językowe PWN” 2017, https://sjp.pwn.pl/poradnia/ haslo/i-Dezinformacja-i-a-i-falszywe-informacje-i;18184.html.

Dynarski W., Kłonkowska A.M., Gender i inne kłopotliwe terminy. Czyli jak mówić o różnorodności i (nie)normatywności płciowej i seksualnej, [w:] U. Kluczyńska, W. Dynarski, A.M. Kłonkowska, Poza schematem. Społeczny konstrukt płci i seksualności, Gdańsk 2016, s. 11-20.

Jones C., Slater J., The toilet debate: Stalling trans possibilities and defending "women's protected spaces", „The Sociological Review” 68, 2020, nr 4, s. 834-851.

Kamiński Ł., Bohaterka, na jaką ludzkość nie zasługuje. Jak Dolly Parton przyłożyła się do walki z koronawirusem, wyborcza.pl, 2020, https://wyborcza.pl/7,113768,26520888,bohaterka-na-jaka-ludzkosc-nie-zasluguje-jak-dolly-parton.html.

Kuta N., Feminizm musi być trans-inkluzywny albo będzie martwy, „Codziennik Feministyczny” 2020, http://codziennikfeministyczny.pl/feminizm-musi-byc-trans-inkluzywny-albo-bedzie-martwy/.

PATH position on "Rapid-Onset Gender Dysphoria (ROGD)", WPATH, 2018, https://www.wpath.org/ media/cms/Documents/Public\%20Policies/2018/9_Sept/WPATH\%20Position\%20on\%20Rapid-Onset\%20Gender\%20Dysphoria_9-4-2018.pdf.

Pearce R., Erikainen S., Vincent B., TERF wars: An introduction, „The Sociological Review” 68, 2020, nr 4, s. 677-698.

Romanowska K., Mam watpliwości, czy zamiana „kobiet” na „osoby z macicami” to postawa lewicowa. Wywiad z Urszula Kuczyńska, ,Wysokie Obcasy” 2020, https://www.wysokieobcasy.pl/wysokie-obcasy/7,163229,26597103,kobiety-w-polsce-jeszcze-nie-zajely-miejsca-na-scenie.html.

Soll J., The long and brutal history of fake news, „Politico Magazine”, 2016, https://www.politico.com/ magazine/story/2016/12/fake-news-history-long-violent-214535.

Trans Rights Europe \& Central Asia Index 2020, TGEU, https://tgeu.org/trans-rights-europe-centralasia-index-maps-2020/.

Transgender hate crimes recorded by police go up 81\%, BBC, 2019, https://www.bbc.com/news/uk48756370.

Uzasadnienie do weta prezydenta: Ustawa o uzgodnieniu płci może prowadzić do destabilizacji norm społecznych, „Dziennik Gazeta Prawna” 2015, https://prawo.gazetaprawna.pl/artykuly/897813, uzasadnienie-do-weta-prezydenta-ustawa-o-uzgodnieniu-plci-moze-prowadzic-do-destabilizacj i-norm-spolecznych.html.

Zabdyr-Jamróz M., 3 mity na temat „Standardów edukacji seksualnej” WHO, Instytut Zdrowia Publicznego Collegium Medicum Uniwersytetu Jagiellońskiego, https://izp.wnz.cm.uj.edu.pl/pl/blog/3mity-na-temat-standardow-edukacji-seksualnej-who/.

Dziennikarstwo i Media 14, 2020

(C) for this edition by CNS 